\title{
In vitro anti-staphylococcal activity of Hyptis martiusii Benth against methicillin-resistant Staphylococcus aureus-MRSA strains
}

\author{
Henrique D. M. Coutinho, ${ }^{*, 1}$ José G. M. Costa, ${ }^{1}$ José P. Siqueira-Júnior, ${ }^{2}$ Edeltrudes $O$. \\ $\operatorname{Lima}^{3}$
}

${ }^{1}$ Laboratório de Pesquisa em Produtos Naturais, Departamento de Ciências Físicas e Biológicas, Universidade Regional do Cariri, 63100-000 Crato-CE, Brazil,

${ }^{2}$ Laboratório de Genética de Microrganismos, Departamento de Biologia Molecular, Universidade Federal da Paraíba, 58051-900 João Pessoa-PB, Brazil,

${ }^{3}$ Laboratório de Micologia, Departamento de Ciências Farmacêuticas, Universidade Federal da Paraíba, 58051-900, João Pessoa-PB, Brazil

\begin{abstract}
RESUMO: “Atividade anti-estafilocócica in vitro de Hyptis martiusii Benth contra linhagens de Staphylococcus aureus resistentes à meticilina - MRSA”. Este é o primeiro relato de atividade antibacteriana de Hyptis martiusii Benth. Neste estudo, o extrato etanólico de H. martiusii foi avaliado para atividade antimicrobiana contra linhagens de Escherichia coli, Pseudomonas aeruginosa e Staphylococcus aureus. O crescimento de todas as bactérias testadas foi inibido pelo extrato. O diâmetro das zonas de inibição variaram de 13 - $20 \mathrm{~mm}$. Os valores da CIM e CBM variaram de 128 a $\geq 1024$ mg/mL e 256 a $\geq 1024$ mg/mL, respectivamente. Devido a isso, podemos indicar que o extrato etanólico de $H$. martiusii pode ser usado como um agente anti-Staphylococcus. Quando comparado com outros antibióticos como meticilina e gentamicina, o extrato foi mais efetivo, demonstrando ser um promissor agente antibacteriano.
\end{abstract}

Unitermos: Hyptis martiusii, Labiatae, atividade anti-estafilocócica, atividade antimicrobiana.

\begin{abstract}
This is the first report about the antibacterial activity of Hyptis martiusii Benth. In this study the ethanol extract of $H$. martiusii was tested for its antimicrobial activity against strains of Escherichia coli, Pseudomonas aeruginosa and Staphylococcus aureus. The growth of all bacterial strains tested was inhibited by the extract. The diameter of inhibition zones varied from 13 to $20 \mathrm{~mm}$ for the extract. The MIC and MBC values ranged from 128 to $\geq 1024 \mathrm{mg} / \mathrm{mL}$ and 256 to $\geq 1024 \mathrm{mg} / \mathrm{mL}$, respectively. It is therefore suggested that extracts from $H$. martiusii could be used as an anti-Staphylococcus agent. Compared with methicillin and gentamicin, the extract was more effective, being a promising antibacterial agent.
\end{abstract}

Keywords: Hyptis martiusii, Labiatae, anti-staphylococcal activity, antimicrobial activity.

\section{INTRODUCTION}

Staphylococcus genus is widely spread in nature being part of the indigenous microbiota of skin and mucosa of animal and birds. Some Staphylococcus species are frequently recognized as etiological agents of many animal and human opportunistic infections (Nostro et al., 2004). S. aureus, S. epidermidis, S. saprophyticus and $S$. haemolyticus are the most important species as community and nosocomial human infection causing agents. In addition of causing different kinds of intoxications, S. aureus has been the most common etiological agent of festering infections that attack different tissues and/or organs (e.g. furuncle, carbuncle, abscess, myocarditis, endocarditis, pneumonia, meningitis, bacterial arthritis) (Verhoeff et al., 1999; Pereira et al., 2004). Capsule, peptidoglican, teicoic acids, adesins and synthesis of enzymes and extracelullar toxins are some virulence attributes present in/on S. aureus cell (Nostro et al., 2004).

Among the bacterial genera able to develop changes in their sensitivity to antimicrobials, Staphylococcus species have been recognized as having increasing and worrying antimicrobial resistance (Georgopapadakou, 2002; Nostro et al., 2004). For patients, the antimicrobial resistance increases the morbidity and mortality, whilst for healthcare institutions it means increasing costs (Dancer, 2001; Coutinho et al., 2005). Regarding the increasing clinical importance given to nosocomial and community bacterial infections and the progressive development of antimicrobial resistance, a great number of scientific researches emphasizing the antibacterial properties of plant products has been carried out (Hernández et al., 2003; Silva-Santos et al., 2004; Duarte et al., 2005; Gayoso et al., 2005; Michelin et al., 2005; Lima et al., 2006a,b; 
Santos et al., 2007; Serafin et al., 2007; Silva et al., 2007; Aguiar et al., 2008; Silva et al., 2008; Salvagnini et al., 2008; Simões et al., 2008). Filtrates, infusions, macerated, juices, extracts and cataplasms from plants with medicinal properties have been applied in the treatment of various diseases since antiquity (Annuk et al., 1999; Hernández et al., 2003).

Hyptis martiusii Benth ("cidreira-do-campo") is a small shrub belonging to family Labiatae used in Brazilian traditional medicine against intestinal and stomachic diseases (Agra et al., 2008), with few pharmacological reports. Antitumoral, cytotoxic and insecticidal activities were identified (Araújo et al., 2003; Costa-Lotufo et al., 2004; Costa et al., 2005; Araújo et al., 2006), but no antimicrobial activity has so far been reported according to a literature survey.

Chemical compounds as flavonoids (Isobe et al., 2006), triterpenes (Falcão et al., 2003), diterpenes (Ohsaki et al., 2005) and sesquiterpenes (Facey et al., 2005), with antimicrobial, insecticidal, analgesic, antiplasmodial activities and antidepressive effect (Okiemy-Andissa et al., 2004; Fragoso-Serrano et al., 2005; Chukwujekwu et al., 2005; Isobe et al., 2006; Silva et al., 2006; Bueno et al., 2006) were isolated on other plants from the genus Hyptis.

This study was carried out with the purpose of evaluating the antimicrobial effect of the ethanolic extract of $H$. martiusii to inhibit the growth and survival of $S$. aureus strains isolated from clinical samples.

\section{MATERIAL AND METHODS}

\section{Drugs}

Methicillin (SIGMA), Gentamicin (SIGMA). The solutions of antibiotics were prepared using the recommendations of Clinical and Laboratory Standards Institute - CLSI (NCCLS, 2003).

\section{Strains}

Escherichia coli (ATCC 8539 and ATCC10536), Pseudomonas aeruginosa (ATCC 25619 and 9027), Staphylococcus aureus (ATCC 6538 and 25923) were used as positive control. The clinical and methicillinresistant Staphylococcus aureus (MRSA) were obtained from the Laboratório de Genética de Microrganismos - UFPB. All strains were stocked at room temperature in heart infusion agar slants (HIA, Difco) and, prior to assay, the cells were grown overnight at $37^{\circ} \mathrm{C}$ in brain heart infusion (BHI, Difco).

\section{Plant material}

Leaves of Hyptis martiusii were collected in the city of Crato, State of Ceará, Brazil. The plant material was identified by Dra. Maria Arlene Pessoa da Silva and voucher specimen have been deposited with the number 464 at Herbarium "Dárdano de Andrade Lima" of Universidade Regional do Cariri - URCA.

\section{Preparation of ethanol extract from Hyptis martiusii (EEHM)}

$200 \mathrm{~g}$ of aerial parts were oven-dried at room temperature and powdered. The powdered material was extracted by maceration using $1 \mathrm{l}$ of $95 \%$ ethanol as solvent at room temperature. The mixture was reserved for $72 \mathrm{~h}$ at room temperature. The extracts were then filtered and concentrated under vacuum in rotatory evaporator (Brasileiro et al., 2006). For the tests, the extract was diluted in DMSO and its highest concentration remaining after dilution into broth caused no inhibition of bacterial growth.

\section{Antimicrobial activity test}

Solid medium diffusion technique using agar wells was used for screening the antibacterial activity. For this, $1 \mathrm{ml}$ of the bacterium suspension (approximately $10^{5} \mathrm{cfu} / \mathrm{ml}$ ) was uniformly spread on sterile agar Muller-Hinton Petri dishes. $50 \mu \mathrm{l}$ of EEHM $10 \mathrm{mg} / \mathrm{mL}$ were addicted within agar wells with $6 \mathrm{~mm}$ diameter (modified from Nair et al., 2005; Sahin et al., 2004). The system was incubated at $37^{\circ} \mathrm{C}$ for 24 hours. It was considered as positive antibacterial activity when observed growth inhibition zone with diameter $\geq 10 \mathrm{~mm}$ diameter (Lima et al., 1993). MICs were determined in a microtitre assay (Javadpour et al., 1996) by inoculation of $100 \mu \mathrm{L}$ of each strain suspended in BHI two - fold concentrated (final concentration $10^{5}$ colony-forming units/mL) in a 96-well microtitre tray with two-fold serial dilutions by adding $100 \mu \mathrm{L}$ of EEHM solution. The final concentrations of the EEHM was 512, 256, 128, 64, 32, 16 and $8 \mu \mathrm{g} / \mathrm{mL}$. The MICs were recorded as the lowest concentration for growth inhibition. The Minimal bactericidal concentration (MBC) was determined inoculating samples from non - growth wells on plates with BHI agar. The MRSA strains 007 and 441 were assayed with methicillin and gentamicin with final concentrations of 1024, 512, 256, 128, 64, 32, 16, 8, 4, 2 and $1 \mu \mathrm{g} / \mathrm{mL}$. All plates were incubated aerobically for $24 \mathrm{~h}$ at $37^{\circ} \mathrm{C}$. The MBCs were recorded as the lowest concentration without growth. All antimicrobial assays were performed twice and the results were expressed as average of the two repetitions.

\section{Abbreviations}

Oxacillin (OXA); Penicillin (PEN); inductive Erythromycin (EM); Kanamycin (KAN); Streptomycin (SM); Gentamicin (GEN); Amikacin (AMI); Tobramycin (TOB); Chloramphenicol (CHL); Tetracyclinminocyclin (TCM); Neomycin (NEO); Paramomycin 
(PARA); Butirosin (BUT); Sisomicin (SIS); Netilmicin (NET); Constitutive Erythromycin $\left(\mathrm{ERI}^{\mathrm{C}}\right)$; Tetracyclin (TC); Ampicillin (AMP); Amoxicillin (AMOX); Cefalotin (CF); Cefadroxil (CFR); Cefalexin (CFL); Clindamycin (CN); Ciprofloxacin (CIP); Gatifloxacin (GAT); Ampicillin-Sulbactan (AMPS); Rifampicin (RIF); Novobiocin (NOV).

\section{RESULTS AND DISCUSSION}

In the last years there has been a great scientific interest in chemical and pharmacological investigations regarding the biological properties of medicinal plants (Almeida et al., 2001; Silva et al., 2003; Rocha et al., 2005; Barbosa-Filho et al., 2005; Barbosa-Filho et al., 2006a,b,c; Saúde-Guimarães \& Faria, 2007; BarbosaFilho et al., 2007; Biavatti et al., 2007; Oliveira et al., 2007; Barbosa-Filho et al., 2008). It is known that medicinal plants have been source of many drugs applied in clinical procedures (e.g morphine, emetine, rutine). The use of extracts as antimicrobial agents presents a low risk of rising microbial resistance to their action because are complex mixtures, making more difficult the microbial adaptability (Daferera et al., 2003).

Table 1 shows the inhibitory activity of EEHM against clinical isolates of $S$. aureus. EEHM showed effectiveness in inhibiting the all strains with inhibition zones between 13-20 mm (average: 16,5 \pm 1.8 ). Six strains showed inhibition zones with diameter $\geq 18 \mathrm{~mm}$.
Smallest inhibition zones $(13 \mathrm{~mm})$ were found on the MRSA strain 358, while the largest one $(20 \mathrm{~mm})$ were found on the MRSA strains 365, 10C and 19L. MIC and MBC values were $128-512 \mu \mathrm{g} / \mathrm{mL}$ and $256 \geq 1024 \mu \mathrm{g} /$ $\mathrm{mL}$ for the $S$. aureus strains, respectively. The effect was not observed on the P aeruginosa and E. coli strains. As far as we know, it is the first report of the antimicrobial activity of $H$. martiusii.

Table 2 shows the anti-staphylococcal efficacy of EEHM when compared with the aminoglycoside gentamicin and the $\beta$-lactam methicillin. The EEHM was 2 - 4 times more effective to inhibit the S. aureus growth than these drugs. Regarding the MIC values found for all assayed $S$. aureus strains, the classification criteria above cited confirms the strong anti-staphylococcal property of EEHM.

Plants remaining to the genus Hyptis are used in the folk medicine by populations around the world as an antimicrobial remedy (Goun et al., 2003; Wiart et al., 2004; Kala, 2005). These antimicrobial properties have been assayed and proven in ethanol extracts and essential oils of H. ovalifolia (Hasimoto and Souza et al., 2002; Souza et al., 2003), in methylene chloride extract from $H$. brevipes (Goun et al., 2003). Furthermore, flavones from H. suaveolans (Isobe et al., 2006) and pectinolides from H. pectinata (Fragoso-Serrano et al., 2005) showed antibacterial activity against Helicobacter pylori, E. coli and $S$. aureus respectively.

The results obtained in this study showed

Table 1. Origin, resistance profile of Staphylococcus aureus strains and inhibitory activity of Hyptis martiusii.

\begin{tabular}{|c|c|c|c|c|c|}
\hline Strain & Origin & $\mathrm{PRP}^{\mathrm{a}}$ & $\begin{array}{c}\text { Inhibition } \\
(\mathrm{mm})\end{array}$ & $\mathrm{MIC}(\mu \mathrm{g} / \mathrm{mL})$ & $\begin{array}{c}\mathrm{MBC} \\
(\mu \mathrm{g} / \mathrm{mL})\end{array}$ \\
\hline E. coli ATCC10536 & - & - & 11 & 512 & $\geq 1024$ \\
\hline E. coli ATCC8539 & - & - & 16 & $\geq 1024$ & $\geq 1024$ \\
\hline P. aeruginosa ATCC25619 & - & - & 16 & $\geq 1024$ & $\geq 1024$ \\
\hline P. aeruginosa ATCC9027 & - & - & 17 & $\geq 1024$ & $\geq 1024$ \\
\hline S. aureus ATCC6538 & - & - & 15 & 256 & 512 \\
\hline S. aureus ATCC25923 & - & - & 15 & 256 & 512 \\
\hline MRSA 06C & surgical wound & 1 & 18 & 512 & $\geq 1024$ \\
\hline MRSA 365 & surgical wound & 2 & 20 & 256 & 512 \\
\hline MRSA 358 & surgical wound & 2 & 13 & 128 & 256 \\
\hline MRSA 296I & abscess & 3 & 14 & 512 & $\geq 1024$ \\
\hline MRSA $171 \mathrm{C}$ & surgical wound & 4 & 14 & 256 & 512 \\
\hline MRSA 015 & surgical wound & 2 & 14 & 512 & $\geq 1024$ \\
\hline MRSA $02 \mathrm{H}$ & surgical wound & 5 & 19 & 256 & 512 \\
\hline MRSA 01 & windpipe secretion & 6 & 14 & 512 & $\geq 1024$ \\
\hline MRSA 007 & surgical wound & 2 & 19 & 256 & 512 \\
\hline MRSA $05 \mathrm{H}$ & surgical wound & 7 & 17 & 128 & 256 \\
\hline MRSA 441 & surgical wound & 2 & 15 & 256 & 512 \\
\hline MRSA 10C & surgical wound & 8 & 20 & 256 & 512 \\
\hline MRSA $192 C$ & surgical wound & 2 & 14 & 512 & $\geq 1024$ \\
\hline MRSA 19L & surgical wound & 9 & 20 & 256 & 512 \\
\hline
\end{tabular}

A - Phenotipic Resistance Profile - PRP: 1 - Oxa, Pen, Em², Kan, Sm, Gen, Ami, Tob, Chl, Rif, Nov; 2 - Oxa, Gen, Tob, Ami, Kan, Neo, Para, But, Sis, Net; 3 - Oxa, Pen, Em¹, Kan, Sm, Gen, Ami, Tob, Rif; 4 - Oxa, Pen, Em ${ }^{\mathrm{I}}$ Kan, Sm, Gen, Ami, Tob, Tcm; 5 - Oxa, Pen, EmI, Kan, Sm, Gen, Ami, Tob, Chl, Tcm; 6 - Oxa, Amp, Amox, Cf, Cfr, Cfl, Cn, Cip, Gen, Gat, Pen, Amps; 7 - Oxa, Pen, Eri ${ }^{\mathrm{C}}$, Kan, Sm, Gen, Ami, Tob, Tcm; 8 - Oxa, Pen, Eri' ${ }^{\mathrm{C}}$, Kan, Sm, Gen, Ami, Chl, Tc; 9 - Oxa, Pen, Em ${ }^{\mathrm{I}}$ Kan, Sm, Gen, Ami, Tob, Chl,Tcm. 
Table 2. Comparative effect of the ethanol extract of Hyptis martiusii (EEHM) and antibiotics against strains of Staphylococcus aureus isolated from clinical material.

\begin{tabular}{cccc}
\hline Strain & MIC Methicillin $(\mu \mathrm{g} / \mathrm{mL})$ & MIC Gentamicin $(\mu \mathrm{g} / \mathrm{mL})$ & MIC EEHM $(\mu \mathrm{g} / \mathrm{mL})$ \\
\hline MRSA 441 & $\geq 1024$ & $\geq 1024$ & 256 \\
MRSA 007 & $\geq 1024$ & $\geq 1024$ & 512 \\
\hline
\end{tabular}

the strong anti-staphylococcal property of the ethanol extract of $H$. martiusii, noted by small MIC value and effectiveness in inhibiting the microbial growth of $S$. aureus. These data are promising and could encourage further researches on phytochemical, toxicological and pharmacological aspects of $H$. martiusii by-products in order to support their possible rational use in the antimicrobial therapy, particularly, in anti-S. aureus therapy.

\section{ACKNOWLEDGEMENTS}

This work was supported by the following Brazilian agencies CNPQ and FAPESQ/PB.

\section{REFERENCES}

Agra MF, Silva KN, Basílio IJLD, França PF, Barbosa-Filho JM 2008. Survey of medicinal plants used in the region Northeast of Brazil. Rev Bras Farmacogn 18: 472-508.

Aguiar JS, Costa MCCD, Nascimento SC, Sena KXFR 2008. Atividade antimicrobiana de Lippia alba (Mill.) N. E. Brown (Verbenaceae). Rev Bras Farmacogn 18: 436-440.

Almeida RN, Navarro DS, Barbosa-Filho JM 2001. Plants with central analgesic activity. Phytomedicine 8: 310-322.

Annuk H, Hirmo S, Turi E, Mikelsaar M, Arak E, Wadstrom $\mathrm{T}$ 1999. Effect on cell surface hydrophobicity and susceptibility Helicobacter pylori to medicinal plant extracts. FEMS Microbiol Lett 172: 41-45.

Araújo ECC, Silveira ER, Lima MAS, Andrade-Neto M, Andrade IL, Lima MAA 2003. Insecticidal activity and chemical composition of volatile oils from Hyptis martiusii Benth. J Agr Food Chem 51: 3760-3762.

Araújo EC, Lima MA, Montenegro RC, Nogueira M, CostaLotufo LV, Pessoa C, Moraes MO, Silveira ER 2006. Cytotoxic abietane diterpenes from Hyptis martiusii Benth. Z Naturforsch C 61: 177-183.

Barbosa-Filho JM, Vasconcelos THC, Alencar AA, Batista LM, Oliveira RAG, Guedes DN, Falcão HS, Moura MD, Diniz MFFM, Modesto-Filho J 2005. Plants and their active constituents from South, Central, and North America with hypoglycemic activity. Rev Bras Farmacogn 15: 392-413.

Barbosa-Filho JM, Piuvezam MR, Moura MD, Silva MS, Lima KVB, Cunha EVL, Fechine IM, Takemura OS 2006a. Anti-inflammatory activity of alkaloids: A twenty century review. Rev Bras Farmacogn 16: 109-139.

Barbosa-Filho JM, Medeiros KCP, Diniz MFFM, Batista LM, Athayde-Filho PF, Silva MS, Cunha EVL, Almeida JRGS, Quintans-Júnior LJ 2006b. Natural products inhibitors of the enzyme acetylcholinesterase. Rev Bras Farmacogn 16: 258-285.

Barbosa-Filho JM, Martins VKM, Rabelo LA, Moura MD, Silva MS, Cunha EVL, Souza MFV, Almeida RN, Medeiros IA 2006c. Natural products inhibitors of the angiotensin converting enzyme (ACE). A review between 1980-2000. Rev Bras Farmacogn 16: 421446.

Barbosa-Filho JM, Nascimento-Júnior FA, Tomaz ACA, Athayde-Filho PF, Silva MS, Cunha EVL, Souza MFV, Batista LM, Diniz MFFM 2007. Natural products with antileprotic activity. Rev Bras Farmacogn 17: 141-148.

Barbosa-Filho JM, Alencar AA, Nunes XP, Tomaz ACA, Sena-Filho JG, Athayde-Filho PF, Silva MS, Souza MFV, da-Cunha EVL 2008. Sources of alpha-, beta-, gamma-, delta- and epsilon-carotenes: A twentieth century review. Rev Bras Farmacogn 18: 135-154.

Biavatti M, Marensi V, Leite SN, Reis A 2007. Ethnopharmacognostic survey on botanical compendia for potential cosmeceutic species from Atlantic Forest. Rev Bras Farmacogn 17: 640-653.

Brasileiro BG, Pizziolo VR, Raslan DS, Jamal CM, Silveira D 2006. Antimicrobial and cytotoxic activities screening of some Brazilian medicinal plants used in Governador Valadares district. Rev Bras Cienc Farm 42: 195-202.

Bueno AX, Moreira ATS, Silva FT, Estevam CS, Marchioro M 2006. Effects of the aqueous extract from Hyptis pectinata leaves on rodent central nervous system. Rev Bras Farmacogn 16: 317-323.

Chukwujekwu JC, Smith P, Coombes PH, Mulholland DA, van Staden J 2005. Antiplasmodial diterpenoid from the leaves of Hyptis suaveolens. J Ethnopharmacol 102: 295-297.

Costa JGM, Rodrigues FFG, Angélico EC, Silva MR, Mota ML, Santos NKA, Cardoso ALH, Lemos TLG 2005. Chemical-biological study of the essential oils of Hyptis martiusii, Lippia sidoides and Syzigium aromaticum against larvae of Aedes aegypti and Culex quinquefasciatus. Rev Bras Farmacogn 15: 304-309.

Costa-Lotufo LV, Araújo EC, Lima MA, Moraes ME, Pessoa C, Silviera ER, Moraes MO 2004. Antiproliferative effects of abietane diterpenoids isolated from Hyptis martiusii Benth (Labiatae). Pharmazie 59: 78-79.

Coutinho HDM, Cordeiro LN, Bringel KP 2005. Antibiotic resitance of pathogenic bacteria isolated from the population of Juazeiro do Norte - Ceará. Rev Bras Cienc Saúde 9: 127-138.

Daferera DJ, Ziogas BN, Polissiou MG 2003. The effectiveness of plant essential oils on the growth of Botrytis cinerea, Fusarium sp. and Clavibacter michiganensis subsp. michiganensis. Crop Protection 22: 39-44.

Dancer SJ 2001. The problem with cephalosporins. $J$ Antimicrob Chemother 48: 463-478. 
Duarte MCT, Figueira GM, Sartoratto A, Rehder VLG, Delarmelina C 2005. Anti-Candida activity of Brazilian medicial plants. J Ethnopharmacol 97: 305-311.

Facey PC, Porter RB, Reese PB, Williams LA 2005. Biological activity and chemical composition of the essential oil from Jamaican Hyptis verticillata Jacq. J Agr Food Chem 53: 4774-4777.

Falcão DQ, Fernandes SBO, Menezes FS 2003. Triterpenos de Hyptis fasciculata Benth. Rev Bras Farmacogn 13 (Supl.): 81-83.

Fragoso-Serrano M, Gibbons S, Pereda-Miranda R 2005. Anti-staphylococcal and cytotoxic compounds from Hyptis pectinata. Planta Med 71: 278-280.

Gayoso CW, Lima EO, Oliveira VT, Pereira FO, Souza EL, Lima IO, Navarro DF 2005. Sensitivity of fungi isolated from onychomycosis to Eugenia cariophyllata essential oil and eugenol. Fitoterapia 76: 247-249.

Georgopapadakou NH 2002. Infectious disease 2001: drug resistance, new drugs. Drug Resist Update 5: 181191.

Goun E, Cunningham G, Chu D, Nguyen C, Miles D 2003. Antibacterial and antifungal activity of Indonesian ethnomedical plants. Fitoterapia 76: 592-596.

Hasimoto and Souza LK, Oliveira CMA, Ferri PH, Santos SC, Oliveira-Júnior JG, Miranda ATB, Lião LM, Silva MRR 2002. Antifungal properties of Brazilian Cerrado plants. Braz J Microbiol 33: 247-249

Hernández T, Canales M, Avila JG, Duran A, Caballero J, Romo de Vivar A, Lira R 2003. Ethnobotany and antibacterial activity of some plants used in traditional medicine Zapolitán de las Salinas, Puebla (México). J Ethnopharmacol 88: 181-188.

Isobe T, Doe M, Morimoto Y, Nagata K, Ohsaki A 2006. The anti-Helicobacter pylori flavones in a Brazilian plant, Hyptis fasciculata, and the activity of methoxyflavones. Biol Pharm Bull 29: 1039-1041.

Javadpour MM, Juban MM, Lo WC, Bishop SM, Alberty JB, Cowell SM, Becker CL, McLaughlin ML 1996. De novo antimicrobial peptides with low mammalian cell toxicity. J Med Chem 39: 3107-3113.

Kala CP 2005. Ethnomedicinal botany of the Apatani in the Eastern Himalayan region of India. $J$ Ethnobiol Ethnomed 1: 11.

Lima EO, Gompertz OF, Giesbrecht AM, Paulo MQ 1993. In vitro antifungal activity of essential oil obatained from officinal plants against dermatophytes. Mycoses 36: 333-336.

Lima IO, Oliveira RAG, Lima EO, Farias NMP, Souza EL 2006a. Antifungal activity from essential oils on Candida species. Rev Bras Farmacogn 16: 197-201.

Lima MRF, Ximenes CPA, Luna JS, Sant'Ana AEG 2006b. The antibiotic activity of some Brazilian medicinal plants. Rev Bras Farmacogn 16: 300-306.

Michelin DC, Moreschi PE, Lima AC, Nascimento GGF, Paganelli MO, Chaud MV 2005. Evaluation of the antimicrobial activity of vegetal extracts. Rev Bras Farmacogn 15: 316-320.

Nair MKN, Vasudevan P, Venkitanarayanan K 2005. Antibacterial effect of black seed oil on Listeria monocytogenes. Food Control 16: 395-398.
NCCLS 2003. National Committee for Clinical Laboratory Standards. Performance standards of antimicrobial disk susceptibility test. Atlanta, USA.

Nostro A, Blanco AR, Cannatelli MA, Enea V, Flamini G, Morelli I, Roccaro S, Alonzo V 2004. Susceptibility of methicillin-resistant staphylococci to oregano essential oil, carvacrol and thymol. FEMS Microbiol Lett 230: 191-195.

Ohsaki A, Kishimoto Y, Isobe T, Fukuyama Y 2005. New labdane diterpenoids from Hyptis fasciculata. Chem Pharm Bull 53: 1577-1579.

Okiemy-Andissa N, Miguel ML, Etou AW, Ouamba JM, Gbeassor M, Abena AA 2004. Analgesic effect of aqueous and hydroalcoolic extracts of three Congolese medicinal plants: Hyptis suaveolans, Nauclea latifolia and Ocimum gratissimum. Pak J Biol Sci 7: 1613-1615.

Oliveira FQ, Gobira B, Guimarães C, Batista J, Barreto M, Souza M 2007. Espécies vegetais indicadas na odontologia. Rev Bras Farmacogn 17: 466-476.

Pereira MSV, Siqueira-Júnior JP, Takaki GMC 2004. Elimination of resistance to drugs by fluoroquinolones in bovine strains of Staphylococcus aureus. Pesq Vet Bras 24: 11-14.

Rocha LG, Almeida JRGS, Macedo RO, Barbosa-Filho JM 2005. A review of natural products with antileishmanial activity. Phytomedicine 12: 514535.

Sahin F, Gulluce M, Daferera D, Sokmen A, Sokmen M, Polissiou M, Agar G, Ozer H 2004. Biological activities of the essential oils and methanol extract of Origanum vulgare ssp. vulgare in the Eastern Anatolia region of Turkey. Food Control 15: 549557.

Salvagnini LE, Oliveira JRS, Santos LE, Moreira RRD, Pietro RCLR 2008. Avaliação da atividade antibacteriana de folhas de Myrtus communis L. (Myrtaceae). Rev Bras Farmacogn 18: 241-244.

Santos SC, Ferreira FS, Rossi-Alva JC, Fernandez LG 2007. Atividade antimicrobiana in vitro do extrato de Abarema cochliocarpos (Gomes) Barneby \& Grimes. Rev Bras Farmacogn 17: 215-219.

Saúde-Guimarães DA, Faria AR 2007. Substâncias da natureza com atividade anti-Trypanosoma cruzi. Rev Bras Farmacogn 17: 455-465.

Serafin C, Nart V, Malheiros A, Cruz AB, Monache FD, Gette MA, Zacchino S, Cechinel-Filho V 2007. Avaliação do potencial antimicrobiano de Plinia glomerata (Myrtaceae). Rev Bras Farmacogn 17: 578-582.

Silva JS, Moura MD, Oliveira RAG, Diniz MFFM, BarbosaFilho JM 2003. Natural products inhibitors of ovarian neoplasia. Phytomedicine 10: 221-232.

Silva ABL, Dias KS, Marques MS, Menezes IAC, Santos TC, Mello ICM, Lisboa ACCD, Cavalcanti SCH, Marçal RM, Antoniolli AR 2006. Avaliação do efeito antinociceptivo e da toxicidade aguda do extrato aquoso da Hyptis fruticosa Salmz. ex Benth. Rev Bras Farmacogn 16: 475-479.

Silva JG, Souza IA, Higino JS, Siqueira-Junior JP, Pereira JV, Pereira MSV 2007. Atividade antimicrobiana do extrato de Anacardium occidentale Linn. em amostras multiresistentes de Staphylococcus aureus. Rev Bras Farmacogn 17: 572-577. 
Silva MAR, Higino JS, Pereira JV, Siqueira-Júnior JP, Pereira MSV 2008. Antibiotic activity of the extract of Punica granatum Linn. over bovine strains of Staphylococcus aureus. Rev Bras Farmacogn 18: 209-212.

Silva-Santos A, Antunes AMS, Bizzo HR, D’Avila CA, SouzaSantos LC 2004. The application of essential oils and terpenics/terpenoids compounds in the fields of pharmaceutic and cosmetic through the knowledge registered in patents. Rev Bras Farmacogn 14 (Supl. 1): $48-50$.

Simões CC, Araújo DB, Araújo RPC 2008. Estudo in vitro e ex vivo da ação de diferentes concentrações de extratos de própolis frente aos microrganismos presentes na saliva de humanos. Rev Bras Farmacogn 18: 84-89.

Souza LKH, Oliveira CMA, Ferri PH, Oliveira-Júnior JG, Souza-Júnior AH, Fernandes OFL, Silva MRR 2003. Antimicrobial activity of Hyptis ovalifolia towards dermatophytes. Mem Inst Oswaldo Cruz 98: 963965.

Verhoeff J, Beaujean D, Vlok H, Baars A, Meyler A, Van Der Werkwn C, Weersink A 1999. A dutch approach to methicillin-resistance Staphylococcus aureus. Eur J Clin Microbiol Infect Dis 18: 461-466.

Wiart C, Mogana S, Khalifah S, Mahan M, Ismail S, Buckle M, Narayana AK, Sulaiman M 2004. Antimicrobial screening of plants used for traditional medicine in the state of Perak, Peninsular Malaysia. Fitoterapia 75: 68-73 